\title{
Inheritance of Resistance to Colletotrichum acutatum in Fragaria $\times$ ananassa
}

\author{
Béatrice Denoyes-Rothan, Guy Guérin, Estelle Lerceteau-Köhler, and Georgette Risser
}

First and second authors: UREFV, INRA, BP 81, 33883, Villenave d'Ornon Cedex, France; third author: Centre Interrégional de Recherche et d'Expérimentation de la Fraise (CIREF), Lanxade, F-24130, Prigonrieux, France; and fourth author: UGAFL, INRA, Domaine St Maurice, BP94, 84143, Montfavet Cedex, France.

Accepted for publication 29 November 2004.

\begin{abstract}
Denoyes-Rothan, B., Guérin, G., Lerceteau-Köhler, E., and Risser, G. 2005. Inheritance of resistance to Colletotrichum acutatum in Fragaria $\times$ ananassa. Phytopathology 95:405-412.

Anthracnose, caused by Colletotrichum acutatum, is a major disease of the octoploid cultivated strawberry, Fragaria $\times$ ananassa. The inheritance of high and intermediate level plant resistances to $C$. acutatum, patho-

minor genes may also contribute to resistance in cultivars such as Belrubi. The intermediate level of resistance was quantitative and controlled by minor genes. Analysis of 26 genotypes and cultivars from Fragaria spp. showed that the dominant gene was not rare in the germ plasm of $F . \times$ ananassa and that anthracnose resistance was also present in other species of Fragaria. These findings have important implications for anthracnose resistance breeding.
\end{abstract} genicity group 2 , was investigated in an $8 \times 8$ factorial design. A single dominant gene (Rca2) controlled the high-level resistance, although
Additional keywords: host-pathogen interaction, major gene.
Anthracnose, caused by Colletotrichum acutatum Simmonds, is a major disease of the cultivated strawberry (Fragaria $\times$ ananassa Duchesne) in Europe, where C. acutatum is subjected to statutory quarantine requirements (18). Symptoms occur on all parts of the plant, and preferentially on stolons, flowers, and fruits. No chemical disease control methods are available to control the disease effectively. Among cultural techniques, drip irrigation and culturing under plastic tunnels considerably limits inoculum dispersal and therefore reduces fruit losses (20). The use of pathogen-free plants produced according to a scheme of certification usually provides a level of disease control $(24,25)$. Nevertheless, latent infection may occur in apparently healthy plants leading to anthracnose losses in production fields (22). Therefore, the development of strawberry cultivars resistant to $C$. acutatum is promising for controlling anthracnose as a method that is both economical and environmentally acceptable. Screening methods evaluating the reaction of the whole plant have revealed accessions resistant to $C$. acutatum in $F$. $\times$ ananassa $(10,11,16,26,28)$. Studies focused on inheritance of anthracnose resistance have described different modes of resistance $(12,13,32)$. In the study of host-pathogen interaction, Denoyes and Baudry (7) have suggested that the resistance to $C$. acutatum could display different modes of inheritance depending on the pathogenicity group of $C$. acutatum isolate and on the level of resistance.

The objective of this study was to examine the inheritance of high and intermediate level plant resistance to $C$. acutatum isolates of the pathogenicity group 2 in order to improve our understanding of the anthracnose resistance. The inheritance was studied using an $8 \times 8$ factorial design. A thorough analysis of the intermediate resistance was conducted by analyzing the disease

Corresponding author: B. Denoyes-Rothan

E-mail address: denoyes@bordeaux.inra.fr

\section{DOI: 10.1094/PHYTO-95-0405}

This article is in the public domain and not copyrightable. It may be freely reprinted with customary crediting of the source. The American Phytopathological Society, 2005. response of the $S_{2}$ generation from selfing cv. Addie. In addition, a range of 26 geographically diverse accessions of Fragaria spp. was studied for its inheritance of anthracnose resistance. Moreover, a study was carried out for testing the hypothesis that identical major genes are controlling the resistance in cvs. Capitola and Chandler.

\section{MATERIALS AND METHODS}

Plant material. In a preliminary study, four crosses (Valeta $\times$ Selva, Addie $\times$ Sequoia, and their reciprocal crosses Selva $\times$ Valeta and Sequoia $\times$ Addie) were studied in order to test reciprocal effects. Since all these crosses segregated clearly in a 1:1 ratio $(P>0.05)$, a factorial scheme was chosen for studying the inheritance of anthracnose resistance. By using different parents as female and male, this scheme allows the analysis of a broader genetic base compared with that of diallel design. The 16 cultivars used in the factorial crossing scheme $(8 \times 8)$ were assigned randomly as male or female parent (Table 1). Table 1 presents the authors credited with reporting resistance of these cultivars in literature. In addition, the level of resistance of these cultivars is presented according to preliminary or reported results (8). The inheritance of resistance of $\mathrm{cv}$. Addie was studied by inoculating with $C$. acutatum $\mathrm{S}_{2}$ families derived from the selfing of random individuals taken from the $S_{1}$ generation.

The presence of anthracnose resistance to pathogenicity group 2 was evaluated by inoculation of 26 accessions including 23 $F$. $\times$ ananassa genotypes of various geographic origins, one $F$. moschata genotype (FM1), and two F. vesca genotypes (Reine des Vallées and Rodluvan) (Table 2).

Finally, the presence of identical or different genes controlling anthracnose resistance in cvs. Capitola and Chandler was analyzed by studying families derived from the complex cross [(Capitola $\times$ Chandler $) \times$ Pajaro $]$.

Crosses $\left(F_{1}\right.$, first filial generation) and selfings $\left(S_{1}\right.$, selfing parental generation and $S_{2}$, selfing $S_{1}$ generation) were protected from cross-pollination by covering buds with polyethylene bags. 
Seeds were germinated in the greenhouse with a 16 -h photoperiod using supplementary incandescent light and a day temperature of $24 \pm 6^{\circ} \mathrm{C}$ and night temperature of $18 \pm 4^{\circ} \mathrm{C}$. Four to six weeks after sowing, seedlings were transplanted to 72-cell plug trays (one plant per $5 \times 5 \mathrm{~cm}$ well) containing peat/vermiculite substrate (1:1 by volume).

Inoculations. The monoconidial isolate $688 \mathrm{~b}$ of the $C$. acutatum pathogenicity group 2 was used for inoculum (7). The stock culture was maintained in cryoconservation (31). Each year, this strain was recovered from diseased plants of cv. Elsanta to revive its pathogenicity.
Seedlings were inoculated when the first two true leaves were fully developed, i.e., 3 to 4 weeks after planting in the tray. Seedlings were inoculated by spraying the leaf surfaces until runoff with a conidial suspension adjusted to $3 \times 10^{6}$ conidia per milliliter and prepared as described in Denoyes and Baudry (7). After inoculation, the seedlings were maintained in plastic boxes for 2 weeks in a controlled environment growth chamber with a 14-h photoperiod and at $28^{\circ} \mathrm{C} \pm 1{ }^{\circ} \mathrm{C}$, and then for 2 weeks in a greenhouse at $25^{\circ} \mathrm{C} \pm 4^{\circ} \mathrm{C}$. The level of humidity inside the plastic chamber was maintained at 90 to $95 \%$ at least during 1 week after inoculation.

TABLE 1. Parental lines with their pedigrees, origins, resistance reactions, references on resistance to anthracnose, and status in the factorial crossing scheme

\begin{tabular}{|c|c|c|c|c|c|}
\hline Genotype & Parents & Origin & $\begin{array}{l}\text { Resistance } \\
\text { reaction }\end{array}$ & $\begin{array}{l}\text { Reference on resistance } \\
\text { to anthracnose }\end{array}$ & Female or male ${ }^{\mathrm{z}}$ \\
\hline Addie & Pantagruella $\times$ MDUS 3816 & Italy & I & 21 & Male \\
\hline Arking & Cardinal $\times$ Ark $5431($ MDUS $3082 \times$ Delite $)$ & USA (AR) & $\mathrm{R}$ & - & Female \\
\hline Belrubi & Pocahontas $\times$ Redcoat & France & $\mathrm{R}$ & - & Male \\
\hline Chandler & Douglas $\times$ Cal 72361105 & USA (CA-UC) & $\mathrm{R}$ & - & Female \\
\hline Darestival & Brighton $\times$ DA 803717 & France & $\mathrm{S}$ & - & Female \\
\hline Dover & Florida Belle $\times$ Fla 71189 & USA (FL) & $\mathrm{R}$ & 16 & Male \\
\hline Elsanta & Gorella $\times$ Holiday & Netherlands & $\mathrm{S}$ & - & Female \\
\hline Fern & Tufts $\times$ C 6962103 & USA (CA-UC) & $\mathrm{S}$ & - & Male \\
\hline Hokowase & Yakumo $\times$ Tahoe & Japan & $\mathrm{S}$ & 23 & Female \\
\hline HummiGento & - & Netherlands & $\mathrm{S}$ & - & Female \\
\hline Pajaro & Sequoia $\times$ C 637101 & USA (CA-UC) & $\mathrm{S}$ & - & Male \\
\hline Selva & C $703117 \times$ C 51511 & USA (CA-NC) & $\mathrm{R}$ & - & Male \\
\hline Sequoia & C $521615 \times$ C 51511 & USA (CA-NC) & $\mathrm{R}$ & 32 & Male \\
\hline Rosanne & $\mathrm{NC} 3140 \oplus$ & USA (NC) & $\mathrm{R}$ & - & Female \\
\hline Valeta & Sivetta $\times$ Holiday & Netherlands & $\mathrm{S}$ & - & Female \\
\hline Yolo & Hecker $\times$ C 7219805 & USA (CA-UC) & $\mathrm{S}$ & - & Male \\
\hline
\end{tabular}

x Cultivars were rated as S, susceptible; I, intermediate; R, resistant, according to preliminary inoculations and according to Denoyes-Rothan and Guérin (8).

y References of reported resistance for the corresponding cultivar.

${ }^{\mathrm{z}}$ Female or male in the factorial crossing scheme.

TABLE 2. Segregation of $26 \mathrm{~S}_{1}$ populations from genotypes or cultivars for reaction to Colletotrichum acutatum, pathogenicity group 2

\begin{tabular}{|c|c|c|c|c|c|c|c|c|}
\hline \multirow[b]{2}{*}{ Genotype or cultivar $^{\mathrm{V}}$} & \multirow[b]{2}{*}{ Pedigree } & \multirow[b]{2}{*}{ Origin } & \multirow{2}{*}{$\begin{array}{l}\text { No. of } \\
\text { plants }^{\mathrm{W}}\end{array}$} & \multicolumn{3}{|c|}{ Class $^{\mathrm{x}}$} & \multirow{2}{*}{$\begin{array}{l}\text { Ratio } \\
\text { tested }\end{array}$} & \multirow[b]{2}{*}{$P^{\mathrm{z}}$} \\
\hline & & & & $\mathrm{R}$ & MS & VS & & \\
\hline CF1116 & Pajaro $\times$ CF129 & FR & 40 & 2.5 & 27.5 & 70.0 & $0: 1$ & 0.89 \\
\hline Bogota & Zaltbommel 53-116 $\times$ Tugo & NL & 51 & 2.0 & 31.4 & 66.7 & $0: 1$ & 0.73 \\
\hline CF129 & Earlyglow $\times$ Chandler & FR & 52 & 0.0 & 38.5 & 61.5 & $0: 1$ & 0.14 \\
\hline Earliglow & $($ Fairland $\times$ Midland $) \times($ Redglow $\times$ Surecrop $)$ & USA & 15 & 0.0 & 6.7 & 93.3 & $0: 1$ & 0.43 \\
\hline Elsanta & Gorella $\times$ Holiday & NL & 59 & 3.4 & 59.3 & 37.3 & $0: 1$ & 0.90 \\
\hline Darselect & Elsanta $\times$ Parker & FR & 157 & 10.8 & 44.6 & 44.6 & $0: 1$ & 0.01 \\
\hline$\underline{\text { Addie }}$ & Pantagruella $\times$ Md US 3816 & IT & 34 & 38.2 & 61.8 & 0.0 & $0: 1$ & $<0.001$ \\
\hline$\overline{\text { Ostara }}$ & Redgaunlet $\times$ Mach. Dauerernte & NL & 44 & 29.5 & 40.9 & 29.5 & $0: 1$ & $<0.001$ \\
\hline Capitola & CA 75-121-101 × Parker & USA & 151 & 80.1 & 15.9 & 4.0 & $3: 1$ & 0.15 \\
\hline F. moschata FM1 & - & - & 44 & 81.8 & 15.9 & 2.3 & $3: 1$ & 0.30 \\
\hline Gariguette & $($ Pocahontas $\times$ Regina $) \times($ Belrubi $\times$ Marieva $)$ & FR & 161 & 68.9 & 30.4 & 0.6 & $3: 1$ & 0.08 \\
\hline Mamie & Harwester $\times$ Gariguette & FR & 66 & 78.8 & 18.2 & 3.0 & $3: 1$ & 0.48 \\
\hline Mara des Bois & $($ HummiGento $\times$ Ostara $) \times($ Redgaunlet $\times$ Korona $)$ & FR & 224 & 79.5 & 19.2 & 1.3 & $3: 1$ & 0.12 \\
\hline Mme Moutot & Dr Morère $\times$ Royal Sovereign & FR & 24 & 54.2 & 37.5 & 8.3 & $3: 1$ & 0.02 \\
\hline Oso Grande & Parker $\times($ Tioga $\times$ Pajaro $)$ & USA & 56 & 64.3 & 16.1 & 19.6 & $3: 1$ & 0.06 \\
\hline Revada & Climax $\times$ Ada Herzberg & NL & 52 & 78.8 & 21.2 & 0.0 & $3: 1$ & 0.52 \\
\hline Senga Sengana & Markee $\times$ Sieger & GER & 161 & 66.5 & 29.8 & 3.7 & $3: 1$ & 0.01 \\
\hline Seascape & Selva $\times$ Douglas & USA & 200 & 67.5 & 18.5 & 14.0 & $3: 1$ & 0.01 \\
\hline Sequoia & CAL 52.16-15 × CAL 51s1-1 & USA & 76 & 71.1 & 21.1 & 7.9 & $3: 1$ & 0.43 \\
\hline \multirow[t]{2}{*}{$\overline{\mathrm{US} 438}$} & $($ LA $883 \times($ Sunrise $\times($ Midland $\times$ Albritton $))) \times$ & & & & & & & \\
\hline & (FL 76-802 × LA 2556) & USA & 45 & 75.6 & 24.4 & 0.0 & $3: 1$ & 0.93 \\
\hline US70 & FL 73-1965 × FL 73-780 & USA & 106 & 85.8 & 14.2 & 0.0 & $3: 1$ & 0.01 \\
\hline$\underline{\text { Dover }}$ & Florida Belle $\times$ USFL 71-189 & USA & 60 & 91.7 & 6.7 & 1.7 & $1: 0$ & 0.20 \\
\hline$\overline{\text { F. vesca-Reine des Vallées }}$ & - & Europe & 91 & 93.4 & 5.5 & 1.1 & $1: 0$ & 0.25 \\
\hline F. vesca-Rodluvan & - & SWE & 31 & 93.5 & 3.2 & 3.2 & $1: 0$ & 0.52 \\
\hline US159 & LA 7525-A $\times($ Florida Belle $\times$ LA 2556$)$ & USA & 221 & 96.4 & 3.6 & 0.0 & $1: 0$ & 0.72 \\
\hline US292 & Arking $\times$ LA 883 & USA & 146 & 91.8 & 8.2 & 0.0 & $1: 0$ & 0.05 \\
\hline
\end{tabular}

${ }^{\mathrm{v}}$ US70, US159, US292, and US438 were reported as resistant in Galetta et al. (11). Underlined genotypes indicate controls.

w Total number of inoculated plants.

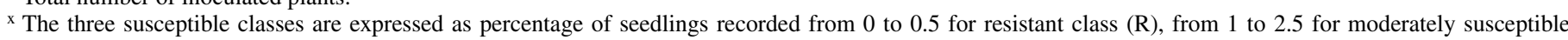
class (MR), and from 3 to 5 for very susceptible class (VS). Notations are evaluated 28 days after inoculation.

y All ratios are for resistant (R) to moderately susceptible and very susceptible (MS + VS) plants.

${ }^{\mathrm{z}}$ Probability of chi-square test calculated for expected ratio 3:1 and likelihood chi-square test calculated for expected ratios 1:0 and 0:1 for goodness of fit. 
Disease responses were recorded 28 days postinoculation according to a scale from 0 (no visual symptoms) to 5 (death of the plant) (7). For summarizing results of inoculations, seedlings were grouped into three categories based on their disease responses: the resistant group [R] (disease responses 0 and 0.5 , which represented no developed visual symptom); the moderately susceptible group [MS] (disease responses from 1 to 2.5, which represented petiolar and/or foliar necrosis); and the very susceptible group [VS] (disease responses from 3 to 5, which represented a wilting reaction due to crown rot).

The Pajaro- $S_{1}$ progeny was included as susceptible control in all inoculation tests of the factorial scheme. Moreover, Elsanta- $S_{1}$, Addie- $S_{1}$, Sequoia- $S_{1}$, and/or Dover- $S_{1}$ progenies were used as a range of controls in the other studies.

Experimental design. In the study of the $8 \times 8$ factorial design, at least 80 seedlings were inoculated for each of the 64 crosses and for the $S_{1}$ progeny of the 16 parents, except for Darestival $\times$ Pajaro, Hokowase $\times$ Pajaro, Hokowase $\times$ Belrubi, Hokowase $\times$ Dover, Elsanta- $S_{1}$, and Rosanne- $S_{1}$, where 49, 44, $59,78,58$, and 48 seedlings were inoculated, respectively. A total of five inoculation experiments were performed and most selfings or crosses were assessed in at least two distinct inoculation experiments. For studying the inheritance of the 26 diverse accessions, at least $40 \mathrm{~S}_{1}$ seedlings were inoculated, except for cv. Madame Moutot (24 seedlings). For studying the inheritance of the intermediate resistance of cv. Addie, one $S_{1}$ and eight $S_{2}$ progeny were inoculated.

Data analysis. For studying segregation in a Mendelian approach, seedlings were grouped into two classes: the resistant class $(\mathrm{R})$ corresponding to $[\mathrm{R}]$ and the susceptible class $(\mathrm{S})$ corresponding to $[\mathrm{MS}]$ and [VS]. Segregation ratios of $\mathrm{S}_{1}$ and cross populations were tested for goodness-of-fit to theoretical ratios for the hypothesis that a single locus with one dominant allele controls resistance. Since seedlings may escape inoculation (mean of $3 \%$ on the eight susceptible $\mathrm{S}_{1}$ cvs. Yolo, Elsanta, Darestival, Pajaro, Fern, Hokowase, Valeta, and HummiGento) or die for other reasons than anthracnose, the segregation ratios 0:1 (resistant/susceptible) and 1:0 (resistant/susceptible) were tested as 3:97 (resistant/susceptible) and 97:3 (resistant/susceptible). Tests were performed on the segregating populations using numerical data. The chi-square $\left(\chi^{2}\right)$ test was used for the segregation ratio $3: 1$ and $1: 1$. The likelihood ratio chi-square test $\left(G^{2}\right)$ (SAS Institute, Cary, NC), which can be performed using a small number of observations (3), was used for the segregation ratios 0:1 and 1:0 (3:97 and 97:3, respectively).

For comparing the disease incidence means of $S_{1}$ and crosses derived from the susceptible or moderately susceptible parents, a least-squares means (LS means) test $(P=0.001)$ was performed. This test was also performed for comparing the eight $S_{2}$ populations derived from cv. Addie with the three $S_{1}$ populations derived from cvs. Addie, Elsanta, and Dover. All analyses were performed using the Statistical Analysis System (SAS Institute).

\section{RESULTS}

Factorial crossing scheme. In the five inoculation experiments, the $S_{1}$ of the susceptible control cv. Pajaro displayed a high percentage of susceptible seedlings from 96 to $100 \%$ ( $P$ of the homogeneity of $\chi^{2}$ test $=0.56$ ), which showed optimum conditions for disease development. Therefore, for each population, data obtained in the different experiments were pooled for analyses.

Frequency distributions of anthracnose disease response appeared to be bimodal except for Addie- $S_{1}$ for HummiGento- $S_{1}$, and for four intercrosses between susceptible cultivars and Addie (Darestival $\times$ Addie, HummiGento $\times$ Addie, Hokowase $\times$ Addie, and Valeta $\times$ Addie). These six distributions showed large percentages of moderately susceptible plants ([MS] of $>20 \%$ ) (Table 3 ).
Major dominant gene for resistance. The $S_{1}$ progeny from the five resistant cultivars, Arking, Chandler, Rosanne, Selva, and Sequoia, segregated clearly in a 3:1 (resistant/susceptible) ratio with $P>0.05$ (Table 4 ), suggesting control by a single heterozygous dominant locus. This control was confirmed in these five resistant cultivars by analysis of the segregation, firstly of the 22 crosses between these five resistant cultivars and the susceptible ones that segregated 1:1 $(P>0.05$ and for three crosses $P>0.01$, except for Arking $\times$ Pajaro and Rosanne $\times$ Fern $[P<0.001$ and $P=0.004$, respectively]), and secondly, of the six intercrosses between resistant cultivars that segregated 3:1 $(P>0.05$, except for Chandler $\times$ Selva $[P=0.002])$ (Table 4).

The $\mathrm{S}_{1}$ progeny from cv. Dover segregated in a 1:0 (resistant/susceptible) ratio $(P>0.05)$, which suggested that the dosage of the resistant dominant allele is at least two (double dose or duplex) (Table 4). Results of the eight $F_{1}$ involving cv. Dover confirmed the presence of a multidose resistant allele in this cultivar because they segregated in a 1:0 (resistant/susceptible) ratio $(P>0.05$ except for two crosses where $P>0.01)$ under the hypothesis of disomic behavior and homozygous status of the gene (Table 4).

In the simplest hypothesis of multidose configuration in the $\mathrm{cv}$. Dover, i.e., double dose, segregations of the resistance gene in disomic (RR rr rr rr), tetrasomic (RRrr rrrr), or octosomic (RRrrrrrr) segregation in configuration of test cross (crosses with susceptible genotypes) and of selfing are presented in Table 5. The results do not support the hypothesis of octosomic inheritance of the resistance gene Rca2 since probabilities of the $\chi^{2}$ were lower than 0.05 , except for HummiGento $\times$ Dover. The observed segregation patterns fit ratios observed in disomic and/or tetrasomic inheritances depending on the crosses.

The observed segregation pattern of Belrubi- $S_{1}$, which displayed a percentage of resistant seedlings of $84.4 \%$, fits neither a $3: 1$ nor a $1: 0$ ratio $(P<0.001)$. Considering the hypothesis of one heterozygous dominant gene, an excess of resistant genotypes was observed in Belrubi- $S_{1}$ and the five crosses between this cultivar and susceptible cultivars (Table 4). However, the three crosses between this cultivar and resistant cultivars segregated clearly in a 3:1 (resistant/susceptible) ratio with $P>0.05$.

Absence of resistance. The $S_{1}$ progenies of susceptible parental cvs. Darestival, Elsanta, Fern, Hokowase, HummiGento, Pajaro, Valeta, and Yolo showed very low percentages of resistant genotypes (from 0.0 to $8.8 \%$ with a mean of $3 \%$ ) (Table 3 ). This result fitted well with the hypothesis of segregation ratio of $0: 1$ (resistant/susceptible) with $P>0.05$. The populations derived from intercrosses between these cultivars followed the same ratio and confirmed the hypothesis of the absence of dominant gene.

Partial resistance. The observed segregation pattern of Addie$\mathrm{S}_{1}$ fitted neither a $0: 1$ nor a $3: 1$ ratio $(P<0.01)$ and nor a $1: 3$ ratio expected with a recessive simplex heterozygous gene $(P<0.01)$ (Table 3). Its frequency of disease response was continuous compared with distributions of the susceptible and resistant controls (Fig. 1). This result suggested a partial resistance.

Using LS mean test, mean disease responses of populations of Addie $-S_{1}$, HummiGento $\times$ Addie, Hokowase $\times$ Addie, and Valeta $\times$ Addie were significantly lower (from 3.3 to 3.0 ) than disease responses of populations of selfings of susceptible cultivars (Darestival, Elsanta, Fern, Hokowase, Pajaro, and Yolo) and lower than intercrosses between these cultivars (from 5.0 to 3.9) (Table 3 ). Moreover, disease responses of five of the eight Addie- $\mathrm{S}_{2}$ families (Addie4-S $\mathrm{S}_{2}$, Addie29-S $\mathrm{S}_{2}$, Addie17-S $\mathrm{S}_{2}$, Addie13- $\mathrm{S}_{2}$, and Addie9- $S_{2}$ ) were significantly lower than disease responses of Addie- $S_{1}$ and similar to Dover $(P=0.001)$ (Table 6). These results suggested that the partial resistance of cv. Addie is under an oligogenic control.

Inheritance of anthracnose resistance to the pathogenicity group 2 in 26 accessions. Disease response segregations to isolate $688 \mathrm{~b}$ are reported in Table 2 for the $S_{1}$ progenies of the 26 
accessions. The segregation ratios of the $S_{1}$ families from cvs. Capitola, Gariguette, Mamie, Mara des Bois, Madame Moutot, Osogrande, Revada, Senga Sengana, and Seascape, from genotypes US438 and US70, and from $F$. moschata FM1 were statistically similar to the segregation ratio of Sequoia- $S_{1}$ and consistent with the hypothesis of a heterozygous locus controlling the high level of resistance. The segregation ratios of the $S_{1}$ families from genotypes US159 and US292 and from both genotypes of F. vesca, Reine des Vallées and Rodluvan, were similar to the $\mathrm{S}_{1}$ from Dover, i.e., homozygous for the resistance locus. The segregation ratios of the $S_{1}$ families from cvs. Bogota, CF1116, CF129, Darselect, and Earliglow were similar to the $S_{1}$ from Elsanta and did not display the dominant allele. As with cv. Addie, cv. Ostara showed too high a level of resistant seedlings for the hypothesis of absence of resistance components.

In order to know if the dominant locus controlling the high level of resistance is the same in the resistant genotypes, a study was carried out using two cultivars, Capitola and Chandler, both heterozygous for the resistance locus. Firstly, cv. Capitola was crossed with cv. Chandler and then individuals from this progeny were crossed with the homozygous susceptible cv. Pajaro. In the hypothesis that the resistance gene is the same in cvs. Capitola and Chandler, families from the crosses [(Capitola $\times$ Chandler $) \times$ Pajaro] will show segregation ratios of 1:0 (resistant/susceptible), 1:1 (resistant/susceptible), and 0:1 (resistant/susceptible) in 25, 50 , and $25 \%$ of the families, respectively. In the hypothesis that the resistance gene is different in cvs. Capitola and Chandler, families from the crosses [(Capitola $\times$ Chandler $) \times$ Pajaro] will segregate with ratios of 3:1 (resistant/susceptible), 1:1 (resistant/susceptible), and 0:1 (resistant/susceptible) for 25, 50, and $25 \%$ of the families, respectively. Among the 21 families analyzed from the crosses [(Capitola $\times$ Chandler $) \times$ Pajaro], nine families segregated $0: 1,11$ families segregated $1: 1$, and one family segregated 1:0, which is consistent with the hypothesis of same major gene in cvs. Capitola and Chandler $(P=0.05)$.

\section{DISCUSSION}

This paper has reported the inheritance of plant resistance to pathogenicity group 2 of $C$. acutatum, the causative agent of anthracnose disease in strawberry, according to the level of resistance.

A major dominant gene controls the high level of resistance. The high level of resistance to this pathogenicity group is controlled by one single dominant gene. The resistant dominant gene was widely present in the collection of European cultivars studied, such as Mamie, Gariguette, and Belrubi, and in U.S. cultivars, such as Sequoia, Dover, and US159. The narrow genetic basis of the cultivated strawberry $(14,27)$ suggests that very few origins of the resistance is involved, which is consistent with the observation of the control of resistance by the same gene in cvs. Capitola and Chandler. Other species of Fragaria displayed resistance to $C$. acutatum, as observed with two genotypes of $F$. vesca and one of $F$. moschata. Anthracnose resistance has also been observed in $F$. chiloensis and F. virginiana (J. L. Maas, personal communication). Further studies of molecular markers

TABLE 3. Resistance to Colletotrichum acutatum, pathogenicity group 2, in segregating Fragaria $\times$ ananassa populations of $\mathrm{S}_{1}$ and $\mathrm{F}_{1}$ progenies from susceptible or moderately susceptible cultivars

\begin{tabular}{|c|c|c|c|c|c|c|c|c|c|c|}
\hline \multirow[b]{2}{*}{ Parental lines and crosses ${ }^{\mathrm{s}}$} & & \multirow{2}{*}{$\begin{array}{c}\text { No. of } \\
\text { test }^{t}\end{array}$} & \multirow{2}{*}{$\begin{array}{l}\text { No. of } \\
\text { plants }^{\mathrm{u}}\end{array}$} & \multicolumn{3}{|c|}{ Class $^{\mathrm{v}}$} & \multirow[b]{2}{*}{ Ratio $^{\mathrm{w}}$} & \multirow[b]{2}{*}{$P^{\mathrm{x}}$} & \multirow[b]{2}{*}{ Mean $^{\mathrm{y}}$} & \multirow[b]{2}{*}{$\mathrm{LS}$} \\
\hline & & & & $\mathrm{R}$ & MS & VS & & & & \\
\hline Darestival $\times$ Pajaro & $\mathrm{F}_{1}$ & 1 & 49 & 0.0 & 0.0 & 100.0 & $0: 1$ & 0.15 & 4.97 & $\mathrm{a}$ \\
\hline Elsanta $\times$ Pajaro & $\mathrm{F}_{1}$ & 2 & 145 & 0.0 & 1.4 & 98.6 & $0: 1$ & 0.02 & 4.94 & $\mathrm{a}$ \\
\hline Elsanta $\times$ Yolo & $\mathrm{F}_{1}$ & 2 & 114 & 0.0 & 3.5 & 96.5 & $0: 1$ & 0.03 & 4.86 & $\mathrm{a}$ \\
\hline Darestival $\times$ Yolo & $\mathrm{F}_{1}$ & 2 & 117 & 0.0 & 3.4 & 96.6 & $0: 1$ & 0.03 & 4.81 & $a b$ \\
\hline HummiGento $\times$ Yolo & $\mathrm{F}_{1}$ & 2 & 168 & 0.6 & 7.7 & 91.7 & $0: 1$ & 0.08 & 4.64 & $a b$ \\
\hline Yolo- $S_{1}$ & $\mathrm{~S}_{1}$ & 3 & 192 & 2.6 & 6.3 & 91.1 & $0: 1$ & 0.81 & 4.63 & $a b$ \\
\hline Darestival $\times$ Fern & $\mathrm{F}_{1}$ & 3 & 143 & 3.5 & 4.9 & 91.6 & $0: 1$ & 0.81 & 4.62 & $a b$ \\
\hline Elsanta- $_{1}$ & $\mathrm{~S}_{1}$ & 2 & 58 & 0.0 & 8.6 & 91.4 & $0: 1$ & 0.12 & 4.61 & $a b$ \\
\hline HummiGento $\times$ Pajaro & $\mathrm{F}_{1}$ & 2 & 203 & 0.5 & 7.4 & 92.1 & $0: 1$ & 0.04 & 4.60 & $\mathrm{ab}$ \\
\hline Valeta $\times$ Fern & $\mathrm{F}_{1}$ & 2 & 86 & 2.3 & 7.0 & 90.7 & $0: 1$ & 0.78 & 4.58 & $a b$ \\
\hline Hokowase $\times$ Pajaro & $\mathrm{F}_{1}$ & 2 & 44 & 0.0 & 9.1 & 90.9 & $0: 1$ & 0.17 & 4.58 & $a b$ \\
\hline Darestival- $S_{1}$ & $\mathrm{~S}_{1}$ & 2 & 225 & 0.9 & 11.6 & 87.6 & $0: 1$ & 0.10 & 4.56 & $a b$ \\
\hline Elsanta $\times$ Fern & $\mathrm{F}_{1}$ & 2 & 117 & 1.7 & 8.5 & 89.7 & $0: 1$ & 0.51 & 4.52 & $a b$ \\
\hline Pajaro- $S_{1}$ & $\mathrm{~S}_{1}$ & 5 & 582 & 1.7 & 8.4 & 89.9 & $0: 1$ & 0.38 & 4.49 & $a b$ \\
\hline Valeta $\times$ Yolo & $\mathrm{F}_{1}$ & 2 & 112 & 3.6 & 8.0 & 88.4 & $0: 1$ & 0.81 & 4.46 & $\mathrm{ab}$ \\
\hline Fern- $S_{1}$ & $\mathrm{~S}_{1}$ & 2 & 110 & 3.6 & 9.1 & 87.3 & $0: 1$ & 0.79 & 4.43 & $\mathrm{abc}$ \\
\hline Valeta $\times$ Pajaro & $\mathrm{F}_{1}$ & 2 & 147 & 2.7 & 12.2 & 85.0 & $0: 1$ & 0.89 & 4.40 & $a b c$ \\
\hline Hokowase $\times$ Yolo & $\mathrm{F}_{1}$ & 2 & 164 & 3.7 & 9.1 & 87.2 & $0: 1$ & 0.74 & 4.37 & $\mathrm{abc}$ \\
\hline Hokowase- $S_{1}$ & $\mathrm{~S}_{1}$ & 2 & 125 & 2.4 & 12.8 & 84.8 & $0: 1$ & 0.77 & 4.35 & $a b c$ \\
\hline HummiGento $\times$ Fern & $\mathrm{F}_{1}$ & 2 & 201 & 5.0 & 13.9 & 81.1 & $0: 1$ & 0.31 & 4.18 & bcd \\
\hline$\underline{\text { Elsanta } \times \text { Addie }}$ & $\mathrm{F}_{1}$ & 5 & 442 & 6.6 & 13.3 & 80.1 & $0: 1$ & 0.01 & 3.95 & cde \\
\hline Valeta $-S_{1}$ & $\mathrm{~S}_{1}$ & 2 & 125 & 8.8 & 16.8 & 74.4 & $0: 1$ & 0.05 & 3.94 & cde \\
\hline Hokowase $\times$ Fern & $\mathrm{F}_{1}$ & 2 & 137 & 11.7 & 18.2 & 70.1 & $0: 1$ & 0.01 & 3.76 & def \\
\hline HummiGento- $S_{1}$ & $\mathrm{~S}_{1}$ & 2 & 143 & 4.9 & 25.9 & 69.2 & $0: 1$ & 0.41 & 3.69 & def \\
\hline$\underline{\text { Darestival } \times \text { Addie }}$ & $\mathrm{F}_{1}$ & 3 & 261 & 5.4 & 24.9 & 69.7 & $0: 1$ & 0.17 & 3.52 & ef \\
\hline HummiGento $\times$ Addie & $\mathrm{F}_{1}$ & 3 & 258 & 10.5 & 27.9 & 61.6 & $0: 1$ & 0.001 & 3.30 & $\mathrm{fg}$ \\
\hline$\underline{\text { Hokowase } \times \text { Addie }}$ & $\mathrm{F}_{1}$ & 3 & 159 & 10.7 & 27.7 & 61.6 & $0: 1$ & 0.01 & 3.27 & $\mathrm{fg}$ \\
\hline$\underline{\text { Valeta } \times \text { Addie }}$ & $\mathrm{F}_{1}$ & 4 & 311 & 14.5 & 28.3 & 57.2 & $0: 1$ & 0.001 & 3.07 & $\mathrm{~g}$ \\
\hline Addie $-S_{1}$ & $\mathrm{~S}_{1}$ & 5 & 695 & 20.4 & 23.9 & 55.7 & $0: 1$ & 0.001 & 2.98 & $\mathrm{~g}$ \\
\hline
\end{tabular}

s Parental lines and crosses are arranged according to their disease response means. Italics indicates selfing ( $\left.\mathrm{S}_{1}\right)$; underline indicates crosses involving cv. Addie.

t Number of inoculation experiment.

u Total number of inoculated plants in all experiments.

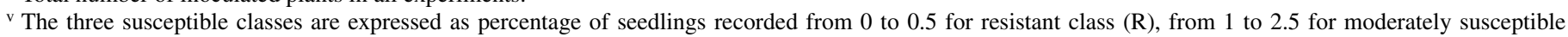
class (MR), and from 3 to 5 for very susceptible class (VS). Notations are evaluated 28 days after inoculation.

${ }^{\mathrm{w}}$ All ratios are for resistant $(\mathrm{R})$ to moderately and very susceptible (MS + VS) plants.

${ }^{x}$ Probability of likelihood chi-square test for goodness of fit.

${ }^{y}$ Mean of disease responses for $S_{1}$ and $F_{1}$ populations.

${ }^{z}$ Disease response mean with same letters do not differ significantly according to least squares (LS) means test at $P=0.001$. 
TABLE 4. Resistance to Colletotrichum acutatum, pathogenicity group 2, in segregating Fragaria $\times$ ananassa populations derived from selfing $\left(\mathrm{S}_{1}\right)$ of resistant cultivars and their crosses $\left(\mathrm{F}_{1}\right)$ between them and with susceptible cultivars

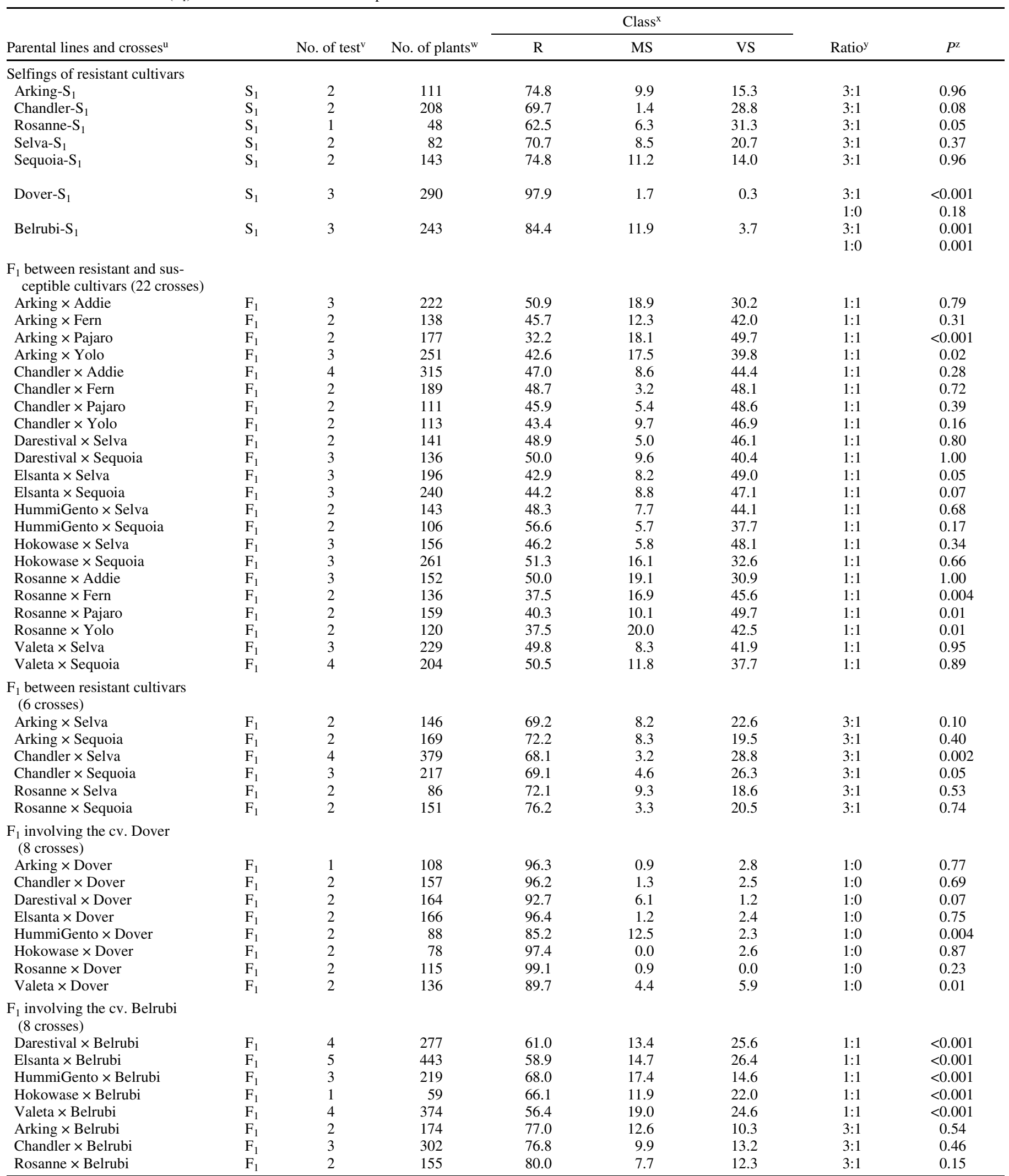

u Parental lines and crosses are ranged according to the population, $\mathrm{S}_{1}$ or $\mathrm{F}_{1}$, and to the ratio.

${ }^{v}$ Number of inoculation experiment.

${ }^{w}$ Total number of inoculated plants in all experiments.

${ }^{\mathrm{x}}$ The three susceptible classes are expressed as percentage of seedlings recorded from 0 to 0.5 for resistant class (R), from 1 to 2.5 for moderately susceptible class (MR), and from 3 to 5 for very susceptible class (VS). Notations are evaluated 28 days after inoculation.

y All ratios are for resistant (R) to moderately and very susceptible (MS + VS) plants.

${ }^{\mathrm{z}}$ Probability of chi-square test calculated for expected ratios 1:1 and 3:1 and likelihood chi-square test calculated for expected ratio 1:0 for goodness of fit. 
TABLE 5. Segregation ratios of the dominant resistance gene in a duplex status in cv. Dover in disomic, tetrasomic, and octosomic inheritance

\begin{tabular}{|c|c|c|c|c|c|c|c|c|c|c|}
\hline \multirow[b]{2}{*}{ Cross $^{v}$} & \multirow{2}{*}{$\begin{array}{l}\text { No. of } \\
\text { plants }^{\mathrm{w}}\end{array}$} & \multicolumn{3}{|c|}{ Class $^{\mathrm{x}}$} & \multicolumn{2}{|c|}{ Disomic behavior } & \multicolumn{2}{|c|}{ Tetrasomic behavior } & \multicolumn{2}{|c|}{ Octosomic behavior } \\
\hline & & $\mathrm{R}$ & MS & VS & Ratio $^{y}$ & $P^{\mathrm{z}}$ & Ratio $^{y}$ & $P^{\mathrm{z}}$ & Ratio $^{y}$ & $P^{\mathrm{z}}$ \\
\hline \multicolumn{11}{|l|}{ Test cross } \\
\hline Darestival $\times$ Dover & 164 & 92.7 & 6.1 & 1.2 & $1: 0$ & 0.07 & $5: 1$ & 0.001 & $11: 3$ & $<0.001$ \\
\hline Elsanta $\times$ Dover & 166 & 96.4 & 1.2 & 2.4 & $1: 0$ & 0.75 & $5: 1$ & $<0.001$ & $11: 3$ & $<0.001$ \\
\hline HummiGento $\times$ Dover & 88 & 85.2 & 12.5 & 2.3 & $1: 0$ & 0.004 & $5: 1$ & 0.63 & $11: 3$ & 0.13 \\
\hline Hokowase $\times$ Dover & 78 & 97.4 & 0.0 & 2.6 & $1: 0$ & 0.87 & $5: 1$ & 0.001 & $11: 3$ & $<0.001$ \\
\hline Valeta $\times$ Dover & 136 & 89.7 & 4.4 & 5.9 & $1: 0$ & 0.01 & $5: 1$ & 0.05 & $11: 3$ & 0.002 \\
\hline \multicolumn{11}{|l|}{ Selfing } \\
\hline Dover-S $S_{1}$ & 290 & 97.9 & 1.7 & 0.3 & $1: 0$ & 0.47 & $35: 1$ & 0.46 & 178:9 & 0.04 \\
\hline
\end{tabular}

$\mathrm{v}$ Test cross for crosses between cv. Dover, which possesses the dominant resistance gene in a duplex status, and susceptible cultivars (no resistance allele).

w Total number of inoculated plants.

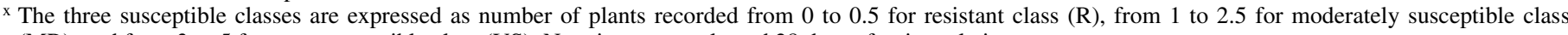
(MR), and from 3 to 5 for very susceptible class (VS). Notations are evaluated 28 days after inoculation.

y All ratios are for resistant (R) to moderately susceptible and very susceptible (MS + VS) plants.

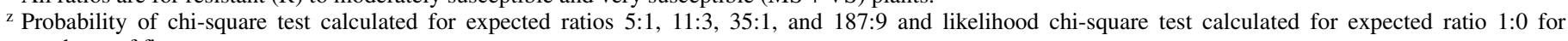
goodness of fit.
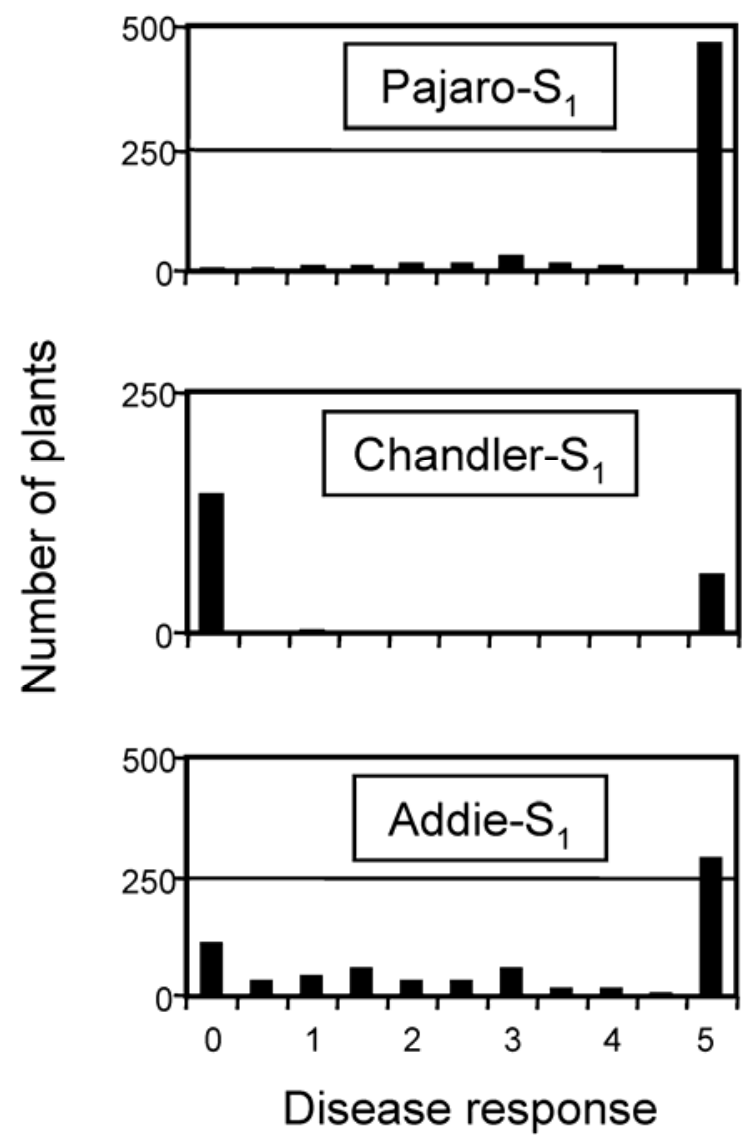

Fig. 1. Frequency distributions of disease response of selfed progeny $\left(S_{1}\right)$ of three cultivars: Pajaro, susceptible; Chandler, resistant; and Addie, intermediate. Disease responses of $0=$ resistant and $5=$ highly susceptible.

linked to resistance would give a better insight of the multiple or single origin of these resistances within the genus Fragaria.

The monogenic resistance agrees with previous work suggesting qualitative inheritance for resistance to C. acutatum (32). However, this study did not mention that the genetic resistance was specifically effective against the pathogenicity group 2 of $C$. $a c u$ tatum. Other studies suggested quantitative inheritance rather than qualitative $(12,13)$. This may be due either to the use of other species of Colletotrichum or other isolates of $C$. acutatum displaying different pathogenicity from the group 2 or to the study of genotypes displaying different mode of inheritance.

Despite the genetic complexity generally assumed in the octoploid strawberry, which displayed regular diploid bivalent pairing during meiosis $(5,17)$, other characters with Mendelian inheritance have been observed in this species such as phosphoglucoisomerase allozymes (4), sex expression (1), photo-insensitivity (day-neutrality) (2), and more recently, resistance to Phytophthora fragariae (30). The behavior of the major resistance gene as disomic, as reported with $R p f 1$ gene (15), or polysomic has not been determined in this study but could be further investigated by the two following approaches: first, by studying the segregation of a multidose resistance gene or molecular markers linked to this gene which will vary according to the mode of inheritance (6), and second, by mapping the major resistance gene on the linkage map of the strawberry genome (19) which will permit observation if this linkage group is in coupling (polysomic behavior) or in coupling/repulsion phase (disomic behavior) (33).

Nomenclature. We proposed to designate the dominant locus Rca2, following suggested nomenclature for resistance gene loci (34) and applied for the first resistance gene described in strawberry by Van de Weg (30). The number 2 refers to the effectiveness of the resistance factor to the isolates of the pathogenicity group 2 described in 1995 (7).

Minor genes control intermediate level of resistance. The intermediate level, reported in cv. Addie, is quantitative and controlled by a complex of minor genes. In cv. Addie, these minor genes could partially display dominant effects since three crosses between cv. Addie and susceptible cultivars were similar for segregation to the Addie- $S_{1}$ progeny. The observation of an excess of resistant seedlings in progenies of crosses between cv. Belrubi and susceptible cultivars compared with the $50 \%$ expected from the control of one single dominant gene further supports the assumption of the presence of minor genes with partial dominance in cv. Belrubi.

In cv. Addie, since transgressive lines of $S_{2}$ display a higher level of resistance than Addie- $S_{1}$ progeny, the intermediate level of resistance can be useful in a breeding program for anthracnose resistance. In addition, this quantitative resistance is expected to act in a non-race-specific manner and then would provide durable resistance according to Van der Plank (29). This agrees with the efficiency of the resistance of cv. Addie against isolates from both pathogenicity groups (B. Denoyes-Rothan, unpublished data).

Correlation with fruit resistance. When we compared the resistance genotype characterized using seedlings with the fruit resistance previously described by Denoyes-Rothan et al. (9), we observed that all genotypes possessing the dominant gene (homozygous or heterozygous) and cv. Addie, which possesses minor genes, displayed intermediate or high level of fruit resistance, while all genotypes without the dominant allele of resistance, except cv. Selva, did not show fruit resistance (Table 7). Therefore, the fruit resistance seems to be controlled partially by the dominant gene but not exclusively. 


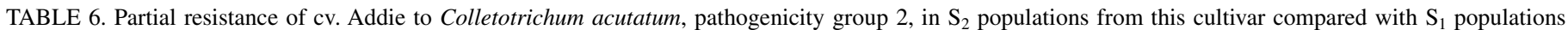
from cvs. Addie, Elsanta, and Dover ${ }^{v}$

\begin{tabular}{|c|c|c|c|c|c|c|c|c|}
\hline \multirow[b]{2}{*}{ Pedigree } & \multirow[b]{2}{*}{ Generation $^{\mathrm{w}}$} & \multirow[b]{2}{*}{ No. of plants ${ }^{\mathrm{x}}$} & \multicolumn{3}{|c|}{ Class $^{\mathrm{y}}$} & \multirow[b]{2}{*}{ Means } & \multirow[b]{2}{*}{$\mathrm{SD}$} & \multirow[b]{2}{*}{ LS means test ${ }^{\mathrm{z}}$} \\
\hline & & & $\mathrm{R}$ & MS & VS & & & \\
\hline Elsanta & $\mathrm{S}_{1}$ & 27 & 0.0 & 33.3 & 66.7 & 3.78 & 1.34 & $\mathrm{a}$ \\
\hline Addie5 & $\mathrm{S}_{2}$ & 87 & 31.0 & 58.6 & 10.3 & 1.47 & 1.28 & b \\
\hline Addie 3 & $\mathrm{~S}_{2}$ & 76 & 44.7 & 34.2 & 21.1 & 1.43 & 1.58 & $\mathrm{~b}$ \\
\hline Addie & $\mathrm{S}_{1}$ & 144 & 52.8 & 34.0 & 13.2 & 1.23 & 1.51 & $\mathrm{~b}$ \\
\hline Addie19 & $\mathrm{S}_{2}$ & 58 & 53.4 & 36.2 & 10.3 & 1.08 & 1.40 & $\mathrm{bc}$ \\
\hline Addie4 & $\mathrm{S}_{2}$ & 92 & 62.0 & 32.6 & 5.4 & 0.83 & 1.12 & $\mathrm{c}$ \\
\hline Addie29 & $\mathrm{S}_{2}$ & 34 & 70.6 & 23.5 & 5.9 & 0.69 & 1.10 & $\mathrm{c}$ \\
\hline Addie17 & $\mathrm{S}_{2}$ & 111 & 73.9 & 21.6 & 4.5 & 0.56 & 1.00 & $\mathrm{c}$ \\
\hline Addie13 & $\mathrm{S}_{2}$ & 30 & 70.0 & 30.0 & 0.0 & 0.53 & 0.81 & $\mathrm{c}$ \\
\hline Addie9 & $\mathrm{S}_{2}$ & 27 & 74.1 & 25.9 & 0.0 & 0.46 & 0.59 & $\mathrm{c}$ \\
\hline Dover & $\mathrm{S}_{1}$ & 27 & 92.6 & 7.4 & 0.0 & 0.13 & 0.43 & $\mathrm{c}$ \\
\hline
\end{tabular}

${ }^{\mathrm{v}}$ Parental lines and crosses are ranged according to the mean of disease response.

${ }^{w} S_{1}$, generation obtained by selfing parental cultivar; $S_{2}$, second selfing generation from parental cultivar.

$\mathrm{x}$ Total number of inoculated plants.

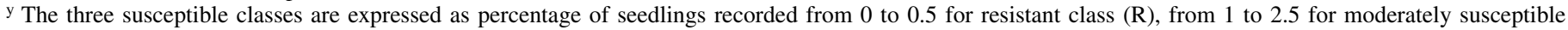
class (MR), and from 3 to 5 for very susceptible class (VS). Notations are evaluated 28 days after inoculation.

${ }^{\mathrm{z}}$ Disease response mean with same letters do not differ significantly according to least squares (LS) means test at $P=0.001$.

TABLE 7. Fruit resistance (disease incidence) and genotype for plant resistance of 22 strawberry cultivars to Colletotrichum acutatum pathogenicity group 2

\begin{tabular}{lccc}
\hline Cultivar & DI $^{\mathrm{x}}$ & $G^{2 \mathrm{y}}$ & $\mathrm{Genotype}^{\mathrm{z}}$ \\
\hline Susceptible & & & \\
Pajaro & 100 & $\mathrm{az}$ & $\mathrm{r} / \mathrm{r}$ \\
Elsanta & 98 & $\mathrm{ab}$ & $\mathrm{r} / \mathrm{r}$ \\
Valeta & 96 & $\mathrm{abc}$ & $\mathrm{r} / \mathrm{r}$ \\
Darestival & 95 & $\mathrm{a}-\mathrm{d}$ & $\mathrm{r} / \mathrm{r}$ \\
Fern & 91 & $\mathrm{a}-\mathrm{d}$ & $\mathrm{r} / \mathrm{r}$ \\
Selva & 89 & $\mathrm{bcd}$ & $\mathrm{R} / \mathrm{r}$ \\
Darselect & 86 & $\mathrm{bcd}$ & $\mathrm{r} / \mathrm{r}$ \\
Intermediate susceptible & & & \\
Seascape & 71 & def & $\mathrm{R} / \mathrm{r}$ \\
Gariguette & 63 & efg & $\mathrm{R} / \mathrm{r}$ \\
Pandora & 58 & efg & - \\
Chandler & 57 & efg & $\mathrm{R} / \mathrm{r}$ \\
Arking & 56 & efg & $\mathrm{R} / \mathrm{r}$ \\
US292 & 51 & e-h & $\mathrm{R} / \mathrm{R}$ \\
Mamie & 44 & fgh & $\mathrm{R} / \mathrm{r}$ \\
Sequoia & 43 & $\mathrm{f}-\mathrm{i}$ & $\mathrm{R} / \mathrm{r}$ \\
Belrubi & 37 & ghi & $\mathrm{R} / \mathrm{r}$ \\
Addie & 33 & ghi & Partial resistance \\
Mara des Bois & 27 & hij & $\mathrm{R} / \mathrm{r}$ \\
Resistant & & & \\
Capitola & 17 & $\mathrm{ij}$ & $\mathrm{R} / \mathrm{r}$ \\
Dover & 16 & $\mathrm{ij}$ & $\mathrm{R} / \mathrm{R}$ \\
US438 & 13 & $\mathrm{ij}$ & $\mathrm{R} / \mathrm{r}$ \\
US159 & 10 & $\mathrm{j}$ & $\mathrm{R} / \mathrm{R}$ \\
\hline
\end{tabular}

${ }^{\mathrm{x}}$ Disease incidence is the percentage of fruit showing an anthracnose lesion 8 days after inoculation. Inoculation was carried out by depositing a drop of inoculum containing 150 conidia on the fruit (8).

${ }^{y}$ Likelihood ratio chi-square test, $G^{2}$, was performed on the distribution of fruit in two classes according to the presence or absence of a lesion. Values with the same letters do not differ significantly $(P<0.001)(8)$

${ }^{\mathrm{z}}$ Plant resistance genotype controlled by a dominant gene in a configuration of diploid deduced from inoculation of $\mathrm{S}_{1}$, except for $\mathrm{cv}$. Addie which showed resistance controlled by minor genes.

A solid understanding of host-pathogen interaction is critical to design an efficient breeding program for disease resistance, which is the lower cost option for the control of anthracnose in strawberry. Genetic components of resistances to both pathogenicity groups have to be incorporated to construct a resistance that is widely efficient since the dominant resistant gene can be overcome by $C$. acutatum isolates from pathogenicity group 1 (7). A selection scheme was proposed to breeders in which the likely quantitative resistance to $C$. acutatum, pathogenicity group 1 , is selected on seedlings at the beginning of selection and the plant resistance to pathogenicity group 2 , conferred by the dominant gene, is selected later after vegetative multiplication on cold stored plants. Studies focused on molecular markers linked to these different components of resistances would provide a better understanding of the resistance and help in the choice of genitors for anthracnose resistance.

\section{ACKNOWLEDGMENTS}

We thank V. Lefebvre and D. Simpson for critical reviews of the manuscript. This research was supported in part by a grant from the "Région Aquitaine" and EEC funds (FEDER).

\section{LITERATURE CITED}

1. Ahmadi, H., and Bringhurst, R. S. 1991. Genetics of sex expression in Fragaria species. Am. J. Bot. 78:504-514.

2. Ahmadi, H., Bringhurst, R. S., and Voth, V. 1990. Modes of inheritance of photoperiodism in Fragaria. J. Am. Soc. Hortic. Sci. 115:146-152.

3. Arbonnier, P. 1966. L'analyse de l'information: Aperçu théorique et application à la loi multinomiale. Ann. Sci. For. 31:57-70.

4. Arulsekar, S., Bringhurst, R. S., and Woth, V. 1981. Inheritance of PGI and LAP isozymes in octoploid cultivated strawberries. J. Am. Soc. Hortic. Sci. 106:679-683.

5. Byrne, D., and Jelenkovic, G. 1976. Cytological diploidization in the cultivated octoploid strawberries $(F$. ×ananassa). Can. J. Genet. Cytol. 18:653-659.

6. Da Silva, J. A. G., and Sobral, B. W. S. 1996. Genetics of polyploids. Pages 1-37 in: The Impact of Plant Molecular Genetics. B. W. S. Sobral, ed. Birkhauser Boston Inc., Cambridge.

7. Denoyes, B., and Baudry, A. 1995. Species identification and pathogenicity study of French Colletotrichum strains isolated from strawberry using morphological, and cultural characteristics. Phytopathology 85:53-57.

8. Denoyes-Rothan, B., and Guérin, G. 1996. Comparison of six inoculation techniques with Colletotrichum acutatum on cold stored strawberry plants and screening for resistance to this fungus in French strawberry collections. Eur. J. Plant Pathol. 102:615-621.

9. Denoyes-Rothan, B., Lafargue, M., Guerin, G., and Clerjeau, M. 1999. Fruit resistance to Colletotrichum acutatum in strawberries. Plant Dis. 83:549-553.

10. Faedi, W., Bagnara, G. L., Turci, P., Winterbottom, C. Q., and De Clauser, R. 1991. Valutazione della suscettibilità ad antracnosi di diversi cloni di fragola. Pages 261-269 in: Nazionale Sulla Fragola. P. Rosati, S. Fraccaroli, and A. Febi, eds. Società Orticola Italiana, Italy.

11. Galetta, G. J., Smith, B. J., and Gupton, C. L. 1993. Strawberry parent clones US70, US159, US292 and US438 resistant to anthracnose crown rot. HortScience 28:1055-1056.

12. Giménez, G., and Ballington, J. R. 2002. Inheritance of resistance to Colletotrichum acutatum Simmonds on runners of garden strawberry and its backcrosses. HortScience 37:686-690.

13. Gupton, C. L., and Smith, B. J. 1991. Inheritance of resistance to Colletotrichum species in strawberry. J. Am. Soc. Hortic. Sci. 116:724727. 
14. Hancock, J., and Luby, J. 1995. Adaptive zones and ancestry of the most important North American strawberry cultivars. Fruit. Var. J. 49:85-90.

15. Haymes, K. M., Henken, B., Davis, T. M., and Van de Weg, W. E. 1997. Identification of RAPD markers linked to a Phytophthora fragariae resistance gene $(\mathrm{Rpf} 1)$ in the cultivated strawberry. Theor. Appl. Genet. 94:1097-1101.

16. Howard, C. M., and Albregts, E. E. 1980. 'Dover' strawberry. HortScience 15:540.

17. Ibrahim, A. M. F., Sadanaga, K., and Denisen, E. L. 1981. Chromosomal behavior in octoploid strawberry progenies and their parental clones during meiosis. J. Am. Soc. Hortic. Sci. 106:522-526.

18. Journal Officiel de la République Française. 1993. Arrété du 2 septembre 1993 relatif aux exigences sanitaires des végétaux, produits végétaux et autres objets. Ministère de l'Agriculture et de la Pêche, Paris, France.

19. Lerceteau-Köhler, E., Guérin, G., Laigret, F., and Denoyes-Rothan, B. 2003. Characterization of mixed disomic and polysomic inheritance in the octoploid strawberry (Fragaria $\times$ ananassa) using AFLP mapping. Theor. Appl. Genet. 107:619-628.

20. Madden, L. V., Xiusheng, Y., and Wilson, L. L. 1996. Effects of rain intensity on splash dispersal of Colletotrichum acutatum. Phytopathology 86:864-874.

21. Maltoni, M. L., Mazzara, M., and Mezzetti, B. 1995. Aspetti patologici, fisiologici e genetici della resistenza a Colletotrichum acutatum e Phytophthora cactorum della fragola. Frutticoltura 7-8:59-66.

22. McInnes, T. B., Black, L. L., and Gatti, J. M. 1992. Disease-free plants for management of strawberry anthracnose crown rot. Plant Dis. 76:260-264.

23. Noguchi, Y., Mochizuki, T., and Yamakawa, O. 1994. Petiole dip inoculation is a convenient method for screening. Bull. Nat. Res. Inst. Veg. Orn. Plants Tea 9:13-20.
24. Nourrisseau, J. G. 1986. Production of small fruit in France: Importance, main diseases and production of healthy plants. Acta Hortic. 186:97-99.

25. OEPP/EPPO. 1994. Certification scheme-pathogen-tested strawberryBulletin. OEPP/EPPO 24:875-889.

26. Simpson, D. W., Winterbottom, C. Q., Bell, J. A., and Maltoni, M. L. 1994. Resistance to a single UK isolate of Colletotrichum acutatum in strawberry germplasm from Northern Europe. Euphytica 77:161-164.

27. Sjulin, T. M., and Dale, A. 1987. Genetic diversity of North American strawberry cultivars. J. Am. Soc. Hortic. Sci. 112:375-385.

28. Smith, B., Gupton, C. L., Galetta, G. J., Maas, J. L., Enns, J. M., Ballington, J. R., Jr., Constantin, R. J., DiVittorio, T. J., and Hilmerick, D. 1998. 'Pelican' strawberry. HortScience 33:1082-1084.

29. Van der Plank, J. E. 1968. Disease Resistance in Plants. Academic Press, New York.

30. Van de Weg, W. E. 1997. Resistance to Phytophthora fragariae var fragariae in strawberry: The Rpf2 gene. Theor. Appl. Genet. 94:10921096.

31. Vegh, I., Konidaris, J., Le Berre, A., Champion, R., Bonnet, P. H., and Besson, P. H. 1988. Conservation des Champignons Phytopathogènes dans l'Azote Liquide après Congélation Progressive Obtenue avec le Minicool. Acta Phytopathol. Entomol. Hungarica 23:81-93.

32. Winterbottom, C. Q. 1991. Resistance of strawberry to Colletotrichum acutatum. MS thesis. University of California, Davis.

33. Wu, K. K., Burnquist, W., Sorrells, M. E., Tew, T. L., Moore, P. H., and Tanksley, S. D. 1992. The detection and estimation of linkage in polyploids using single-dose restriction fragments. Theor. Appl. Genet. 83:294-300.

34. Yoder, O. C., Valent, B., and Chumley, F. 1986. Genetic nomenclature and practice for plant pathogenic fungi. Phytopathology 76:383-385. 